ISSN 1978 - 3000

\title{
Ascites Incidence in Broilers
}

\author{
Nurmeiliasari \\ Jurusan Peternakan, Fakultas Pertanian Universitas Bengkulu \\ Jl. Raya Kandang Limun, Bengkulu 38126, E-mail: sari7599@yahoo.com
}

\begin{abstract}
ABSTRAK
Gejala umum terjadinya sindrom ascites pada ayam broiler adalah berupa akumulasi cairan yang berlebihan di rongga peritoneal yang menyebabkan peningkatan tekanan pembuluh arteri pulmoner. Kondisi ini dapat menyebabkan kematian akibat kurangnya suplai oksigen untuk kebutuhan metabolis tubuh. Angka kematian akibat Ascites pada ayam broiler adalah sebesar 5\%. Sindrom ascites dapat dicegah dengan memperhatikan beberapa factor yaitu lingkungan, manajemen, anatomi dan fisiologi dan genetik. Program pencegahan yang dapat dilakukan untuk menurunkan angka kejadian Ascites pada ayam broiler adalah peningkatan genetik, nutrisi dan lingkungan yang lebih baik.
\end{abstract}

Kata kunci : Ascites, broiler, manajemen, fisiologi, dan genetik.

\section{INTRODUCTION}

The incidence of ascites syndrome or water belly is of increasing concern to the world poultry producers (da Silva et al., 1988; Dale and Villacres, 1988) which causes huge financial loss (Currie, 1999). Some findings mentioned that ascites incidence had caused 5\% mortality rate in commercial meat-type chickens. In addition, the mortality rate of cockerels fed with full diet until 16 weeks of age was 26.3\% (Julian et al., 1987). Ascites syndrome is a metabolic disease which is an accumulation of fluid in peritoneal cavity (da Silva et al., 1988; Luger et al., 2001). It has similarity to high altitude disease, characterized as imbalance of oxygen supply and requirements which leads to mortality on meat-type chickens during winter (Luger et al., 2001).

There are many contributive factors which can induce or can prevent ascites syndrome in broiler chickens. They can be classified as environment factors, management factors, anatomy and physiology factors (Julian, 2000; Balog, 2003), and genetic factors ( Balog et al.,
2003). This paper is aimed to discuss on ascites's symptoms, aetiology and prevention strategies.

\section{ASCITES SYNDROME}

Ascites syndrome is defined as "cascade event", characterized as an accumulative amount of lymph in abdominal cavity (Balog, 2003; da Silva et al., 1988) which may contain fibrin (Julian (1993). In addition, this condition can also be described as lung and heart's "pathophysiological interplay" (Wideman, 2001).

For many years, it has been assumed as pulmonary hypertension syndrome because an increase in pulmonary hypertension which inducing right ventricular failure triggers the incidence of ascites syndrome (Julian, 2000). Generally, starting point of ascites syndrome incidence is an insufficient oxygen supply for metabolic demand (Julian, 2000; Luger et al., 2001; Lott et al., 1996). 
A very common sign of ascites syndrome is an excess of fluid in peritoneal cavity (Balog, 2003; da Silva et al., 1988; Julian, 1993). This syndrome can also be characterized as changes in cardiovascular system to accommodate oxygen requirement (Luger et al., 2001). The changes lead to cardiac abnormalities such as hypertrophy on right ventricular wall which results in an increase in pulmonary arteries pressures (Balog, 2003). This situation can lead to mortality to some chickens because of lung oedema (Julian, 2000). The clinical signs of ascites syndrome which can be observed are impaired vascular and lymphatic system blockage (Balog, 2003), central and portal venous congestion and impaired liver (Wideman et al., 1995). The other clinical signs are cyanosis of body's and head's skin, and degeneration of comb and wattles (Julian, 1993).

\section{CONTRIBUTIVE AND PREVENTIVE FACTORS ON ASCITES SYNDROME INCIDENCE}

The ascites syndrome cannot be categorized as a disease (Julian, 1993). The development of the syndrome can be triggered and also prevented by several factors such as environment, management, anatomy and physiology and genetic (Julian, 2000; Balog, 2003; Balog et al., 2003).

\section{Environmental factors}

Numerous of research has been done to investigate environmental factors which associate to the incidence of ascites syndrome. Three environmental factors induce ascites syndrome are altitude, cold temperature and incubation environment (Julian, 2000; Balog, 2003).

Ascites incidence occurs not only in high altitude poultry farms, but also in low altitude poultry farms. The most common cause of ascites in low and high altitude is pulmonary hypertension (Julian, 1993). Compared to male white leghorn, broiler chickens, which are raised in low altitude, have greater risk to have ascites because of pulmonary hypertension (Julian and Wilson, 1992). A study on broiler susceptibility to ascites which raised in low altitude found that a possible factor in the pathogenesis of ascites in broilers is progressive bradycardia (Olkowski and Classen, 1998).

Increasing altitude is known to lower partial pressure of oxygen. An increase of 500 meter in altitude will decrease the percentage of oxygen by $1 \%$. When birds are raised in high altitude, their haematocrit and blood viscosity increase to compensate with the low level of oxygen availability. As a result, pulmonary hypertension increases which may induced right ventricular failure and increase ascites (Mirsalimi et al., 1993; Julian, 2000). Similarly, all studies reports on birds which grew in high altitude had high blood pressure in pulmonary arteries, hypertrophy on their ventricles, lungs oedema and excess fluid in abdominal cavity. These led to mortality (Balog, 2003).

Cold stress is also known to cause ascites in broiler because of an increase in oxygen metabolic demand ( Balog et al., 2003). Cold exposure on broiler chickens which fed adlibitum increased susceptibility of ascites syndrome by $48 \%$. This study revealed that ascites was caused by insufficient circulatory associated with progressive bradycardia which proceeded by a decrease in heart rate and an increase in haematocrit. It was found that pulmonary hypertension is a secondary symptoms (Olkowski and Classen, 1998).

Another environment factor inducing ascites is incubation 
environment. A study revealed that during incubation and hatching, embryos may experience hypoxic challenge(Balog, 2003) which will induce polycythaemia, low hatchability and produce smaller chicks(Julian, 2000; Currie, 1999). So far, there is no evidence that incubation environment is one of contributive factors since the blood picture of the chicks returns to normal when they were raised in normal environment following the hatch(Julian, 2000). Currie (1999) mentioned that under conditions of induced hypoxia during incubation, cellular changes occurred in some organs such as "granulytic infiltration of heart and testis", and enlargement of heart's mitochondria. Five weeks after hatching, the changes return to normal. As a long term effect of metabolic rate, ascites can possibly triggered by low or high temperature during incubation or after hatching (Julian, 2000).

\section{Management factors}

Management factors play an important role to prevent or to trigger ascites syndrome. The followings are management practices which can be categorized as triggers of ascites : diet, ventilation, aspergillosis and light (Julian, 2000).

There are some aspects of diet which induce ascites syndrome in broiler. Research found that pelleted diet has a positive relationship with the rapid growth of ascites syndrome both in low and high altitude (da Silva et al., 1988). In contrast, mash rations decrease the incidence of ascites syndrome because broiler eats less (Julian, 2000). Da Silva et al. (1988) also mentioned that the incidence of ascites syndrome increase when broiler chickens eat huge amount of dietary fat.

Energy and protein ratio can also induce or prevent ascites syndrome. It is obvious that high-energy ratios can increase growth rate and incidence of ascites because of an increase in oxygen demand. Similarly, feeding low-energy diet can also increase oxygen requirement for digestion because broilers spend more time eating. Therefore, replacement of carbohydrate with vegetable fat will reduce oxygen demand and avoid ascites syndrome (Julian, 2000). Some research suggests that feeding low energy and low protein might prevent the incidence of ascites in broiler chickens aged 0-2 weeks (Julian, 1994; Currie, 1999).

Toxic material in the feed, water and environment can also be the sources of ascites in broiler chickens. Moerover, ascites syndrome was found in broiler chickens fed with low-phosphorus diet (Julian, et al., 1986). Phosphorus deficiency might reduced air capillary hypertension and causes hypoxia (Balog, 2003).

Ventilation is known to be one of the factors inducing ascites. Julian (1993) mentioned that there were reported ascites syndrome which were associated with poor ventilation. However, cold exposure puts greater risks of ascites than poor ventilation. Therefore, reducing ventilation to keep the temperature warm for the broiler chickens will prevent ascites syndrome (Julian, 2000).

Other management factors are Aspergillosis and light. Aspergillosis spores inhalation from mouldy litter or from hatchery can cause lung damage (Julian, 1993). In addition, increase the length of daylight can increase feed intake and ascites susceptibility (Julian, 2000).

Currie (1999) suggests that to control at farm level, the following recommendations may possibly prevent the incidence of ascites syndrome. Firstly, maintaining enough ventilation and oxygen supply in the incubator during hatchery. Secondly, assist broiler chickens 
during the post brooding period to adapt to the environment by slowly lowering the temperature. Thirdly, provide adequate ventilation in the broiler house to remove respiratory irritants. In order to manage energy requirement more accurately, it is important to raise male and female broiler separately. Finally, oxygen demand reduction can be achieved by reducing protein and energy level of diet.

\section{Anatomical and physiological factors}

Rapid growth of broiler chickens is a trigger to ascites because the rapid increase on muscle mass is not followed by an increase in body organ mass. With limitation of vascular capacity in the lung, ascites syndrome can occur (Julian, 2000). Julian (1998) suggests that it might be beneficial to do breed selection on broilers for better vascular capacity.

Broiler chickens need high oxygen demand to support its growth. This need is associated with high cardiac output. An increase pressure and blood flow through the lung can induce ascites because of high pulmonary hypertension (Julian, 2000).

Other physiological triggers are blood viscosity. Blood capillaries of broiler chickens are rigid and small. In addition, its red blood cells are big. In high altitude $(2500 \mathrm{~m})$, blood is very viscous. This condition leads to pulmonary hypertension caused by hypoxic hypoxaemia (Julian, 2000). Anemia can cause right heart failure as cardiac output increases due to an increase in blood volume and a decrease in blood-oxygen affinity (Julian, 1993).

\section{Genetic factors}

Two genetic factors which are associated with oxygen requirement, which trigger ascites syndrome, are metabolic rate and feed efficiency (Julian, 2000). Balog (2003) mentioned that intensive genetic selection for rapid growth and massive meat production of broiler chickens are close to the limit at which their pulmonary system can provide oxygen for growth. Any external stress may induce ascites syndrome because of an increase in oxygen requirement. Another genetic factor is feed efficiency. Feed efficiency improvement and less on growth rate can decrease the incidence of ascites syndrome and is profitable (Julian, 2000). However, minimizing growth of broiler chickens is a tremendous loss of potential (Balog, 2003). There are promising results in recent years, which the impact of ascites syndrome has been decline through selective breeding program. Further, pulse oxymetry and environmental challenge has been good genetic selection strategies to improve genetic resistance of the stock to ascites syndrome (Currie, 1999).

\section{CONCLUSION}

Ascites syndrome is an interlinked problem of heart, respiratory and circulation system. The obvious symptom is an accumulation of lymph/fluid in the abdominal cavity. Ascites syndrome is normally preceded by right ventricular failure and pulmonary hypertension. Multiple factors can trigger the incidence of ascites; such as environment, management, anatomy and physiology, and genetic. These factors can also be preventative factors as well. Therefore, an integrative prevention such as improved genetic material, good nutrition strategies and better environment may minimize the incidence of ascites syndrome.

\section{REFERENCES}

Balog, J.M., B. D. Kidd, W.E. Huff, G.R. Huff, N. C. Rath and N.B. Anthony. 2003. Effect of cold stress on broiler selected for resistance or susceptibility to ascites syndrome. Poultry science 82:1383-87.

Balog, Janice M. 2003. Ascites syndrome (pulmonary hypertension syndrome) in broiler chickens: Are we seeing the light at the end of 
the tunnel? Avian and poultry biology reviews 14(3):99-125.

Buys, N., W. Scheele, C. Kwakernaak, J.D. Van Der Klis and E. Decuypere. 1999. Performance and physiological variables in broiler chicken lines differing in susceptibility to the ascites syndrome: 1 . Changes in blood gases as function of ambient temperature. British poultry science 40:135-39.

Currie, Richard J.W. 1999. Review: ascites in poultry: recent investigations. Avian pathology 28:313-26.

Da Silva, Jose M. L., N. Dale and J. Batista. 1988. Effect of pelleted feed on the incidence of ascites in broilers reared at low altitudes. Avian diseases 32:376-78.

Dale, N., and A. Villacres. 1988. Relationship of two week body weight to the incidence of ascites in broilers. Avian diseases 32:556560.

Julian, R. J. and B. Wilson. 1992. Pen Oxygen Concentration and Pulmonary Hypertension-Induced Right Ventricular Failure and Ascites in Meat-Type Chickens at Low Altitude. Avian Diseases, 36 (3): 733-735.

Julian, R. J., G.W. Friars, H. French and M. Quinton. 1986. The relationship of right ventricular hypertrophy, right ventricular failure, a nd ascites to weight gain in broiler and roaster chickens. Avian diseases 31(1):130-35.

Julian, R.J. and S.M. Mirsalimi. 1992. Blood oxygen concentration of fastgrowing and slow-growing broiler chickens and chickens with ascites from right ventricular failure. Avian diseases 36:730-32.

Julian, R.J., J. Summers and J.B. Wilson. 1986. Right ventricular failure and ascites in broiler chickens caused by phosporus deficient diet. Avian diseases 30(3): 453-59
Julian, Richard J. 1993. Review article: Ascites in poultry. Avian pathology 22:419-454.

Julian, Richard J. 2000. Review article: Physiological, management and environmental triggers of the ascites syndrome: a review. Avian pathology 29:519-527.

Lott, B.D., S.L. Branton and J.D. May. 1996. The effect of photoperiod and nutrition on ascites incidence in broilers. Avian diseases 40:78891.

Luger, D., D. Sinder, V. Rzepakovsky, M. Rusal, and S. Yahav. 2001. Association between weight gain, blood parameters and thyroid hormones and the development of ascites syndrome in broiler chickens. Poultry science 80:96571.

Mirsalimi, S. M., R. J. Julian, and E. J. Squires B. 1993. Effect of hypobaric hypoxia on slow- and fast-growing chickens fed diets with high and low protein levels. Avian Diseases 37:660-667

Mirsalimi, S.M., Peter J. O'Brien and R.J. Julian. 1992. Blood Volume in Increase Salt-induced Pulmonary Hypertension, Heart Failure and in Ascites Broiler and White Leghorn Chickens. Can J. Vet Res 57:110-13

Navarro, P., P.M. Visscher, D. Chatziplis, A.N.M. Koerhuis and C.S. Halley. 2006. Segregation analysis of blood oxygen saturation in broiler suggests a major gene influence on ascites. British poultry science 47(6):671-84.

Olkowski, A. A. and H. L. Classen. 1998. Progressive bradycardia, a possible factor in the pathogenesis of ascites in fast growing broiler chickens raised at low altitude. British Poultry Science 39:139-146

Shlosberg, A., E. Berman, U. Bendheim and I. Plavnik. 1991. Controlled early feed restriction as a potential means of reducing the incidence of ascites in broilers. Avian diseases 35:681-84. 
Wideman, R.F. 2001. Pathophysiology of heart/lung disorders: pulmonary hypertension syndrome in broiler chickens. World's poultry science journal 57:289-307.

Wideman, R.F. and Walter G. Bottje. 1993. Current understanding of ascites syndrome and future research directions. Proceeding of the nutritional and technical symposium. November 1993 in
Springdale, Arkansas and Atlanta, Georgia. Novus international inc. pp. 1-20.

Wideman, R.F., Y.K. Kirby, Walter G. Bottje, R.W. Moore and R.C. Vardeman. 1995. Furosemide reduces the incidence of pulmonary hypertension syndrome (ascites in broilers exposed to cool temperatures. Poultry science 74;314-22. 